\title{
Overview of price discrepancies among hotels positioned in the same category
}

\author{
Zoran Temelkov ${ }^{{ }^{*}}$ \\ ${ }^{1}$ Goce Delčev University of Štip, Faculty of Tourism and Business Logistics, Štip, North \\ Macedonia
}

\begin{abstract}
Hotels have a variety of pricing methods at their disposal when defining adequate pricing strategy. Nevertheless, irrespective of the complexity and the manner in which room prices are calculated all methods are based on certain factors which have an influence on the final room rate. Accordingly, the perception regarding the impact of each factor along with the expected value provided to the customer will cause for hotels to charge different prices. The prices offered on Booking.com for hotels falling in different categories allow examination of the potential price differences among five, four, three and two stars hotels in multiple cities in Europe. The findings suggest that even though two hotels may belong to the same category, their prices may differ few hundreds of per cents which implies that the level of value offered to guests can vary significantly.
\end{abstract}

Keywords: hotel room rate, room price, price strategy, hotel category, Booking.com JEL classification: L83, Z33

\section{Pregled razlike cena među hotelima pozicioniranim u istoj kategoriji}

Sažetak: Hoteli imaju na raspolaganju razne metode određivanja cena prilikom definisanja adekvatne strategije cena. Ipak, bez obzira na složenost i način na koji se izračunavaju cene soba, sve metode se zasnivaju na određenim faktorima koji utiču na konačnu cenu sobe. Shodno tome, percepcija uticaja svakog faktora zajedno sa očekivanom vrednošću koja se pruža kupcu dovešće do toga da hoteli naplaćuju različite cene. Cene koje se nude na Booking.com-u za hotele koji spadaju u različite kategorije omogućavaju ispitivanje potencijalnih razlika u cenama između hotela sa pet, četiri, tri i dve zvezdice u više gradova Evrope. Nalazi sugerišu da, iako dva hotela mogu pripadati istoj kategoriji, njihove cene se mogu razlikovati nekoliko stotina procenata, što znači da nivo vrednosti koji se nudi gostima može značajno da varira.

Ključne reči: cena hotelske sobe, cena sobe, strategija cena, kategorija hotela, Booking.com JEL klasifikacija: L83, Z33

\section{Introduction}

Pricing decision may be one of the most demanding activities for hotel managers and the marketing department since wrong prices may have an adverse effect on hotel profitability or

* zoran.temelkov@ugd.edu.mk 
its customer base. Unjustifiably high price could decrease the number of customers, while a lower price will adversely affect the bottom line. Consequently, managers need to pay attention to the evolution of factors that could potentially affect their pricing decisions and accordingly adapt their pricing strategies.

In their efforts to achieve the objective of setting up an optimal price hotel have plenty of pricing methods available and these methods may be customized to the specific needs or environment. However, due to the increased access to finance and the increase in competition (Jovanović, 2019) hotels should be especially cautious when defining their room rates as inadequate pricing strategy may lead toward overpricing or underpricing of the services provided. Consequently, using different pricing methods may lead to different prices even among hotels falling in the same category or operating the same city.

The purpose of this research is to identify the existence of discrepancies in prices as well as the potential size of these discrepancies, which may appear among hotels in the same category and hotels which operate in the same environment. Hence, a comparison of room price was performed among hotels offering their activities in cities in Europe. Also, the research shows the degree of potential difference in the value offered to customers. The findings suggest that there are price discrepancies in room rates set by hotels in the same category and the differences may be as high as a few thousand per cents.

\section{Literature review}

Evaluating the price differences in the hotel industry may be better understood by looking at the importance of the price and some of the basic pricing strategies used by hotels.

\subsection{Importance of setting the right prices - Implications for correct pricing of hotel services}

In today's economy, customers have more readily available data than ever before which means that they can easily compare products and services offered by different companies. Consequently, companies need to be especially cautious when pricing their products because the inadequate price can mean lost customers or lost revenue. The aforementioned is especially true for companies that offer comparable products as it is the case with the hotel industry.

The hotel industry offers products with a high degree of similarity where those little differences make a significant impact on the pricing decisions and customers' willingness to pay the price. Hence, hotels can gain a competitive advantage when they provide adequate value for money to its customers.

The notion behind "adequate value" deals with the question of whether the price at which the room is sold corresponds to the level of service offered to guests. Noteworthy mentioning is that the possibility for manipulation of room rates is highly limited in today's environment because customers have the opportunity to find prices charged by other hotels at a single website or platform such as Booking.com, TripAdvisor, etc. Hence, the task to set up the optimal prices is even more challenging as there is a direct competition on these platforms.

Furthermore, the pricing decision becomes additionally complicated as guests have the opportunity to evaluate their stay in the specific hotel based on a couple of attributes offered by the online booking platform (Zhang et al., 2011). Consequently, too many negative reviews will limit the maximum price that could be charged by the hotel. On the other hand, an excellent review score may offer the possibility for setting up higher prices (Castro \& Ferreira, 2018). 


\subsection{Determinants of hotel room rates}

Defining a room price is not as easy as it may look at first glance because hoteliers need to consider a plethora of factors which may have a positive or negative impact on the final price. A vast number of factors have been identified and the literature suggests that these factors could be grouped or classified in different manners. For instance, it is suggested that the determinants of hotel room rates can be placed into three broad categories such as costs and expenses, factors associated with the hospitality industry and hotel specific factors (ElNemr et al., 2017).

Also, factors that should be considered may be further classified based on the features, attributes and variables associated with the specific room. Accordingly, they may fall in any of the three types of variables, the tangible variables, reputational variables and contextual variables (Abrate \& Viglia, 2016). Tangible variables are composed of the physical characteristics of hotel products and services and reputational variables account for the ratings and reviews provided by guests on relevant websites and platforms. The contextual variables serve the purpose to include the effect coming from the attributes such as location and the degree of competition.

Traditional and modern factors which arise due to the technological advances and the utilization of technology in the hotel industry is yet another way in which price relevant factors could be grouped. For example, Zhang et al. (2011) argue that aside from the wellknown traditional factors, hotels should also pay attention to the electronic-word-of-mouth as a factor because guests can easily share their experience on online booking platforms or different types of review websites. Other factors which can be placed in the category of modern factors are hotel availability on booking platforms, means of payment (e.g. PayPal or other payment providers), professional and an easy to use website, online presence on different social apps (Facebook, Instagram, WhatsApp), and the level of utilization of modern communication channels (Viber, Twitter, WhatsApp) (Ilić \& Nikolić, 2018).

It can be noted that while supply and demand of hotel services along with the operational costs were the primary factors in the past, today they are representing only the starting point for estimation of optimal room prices. This is in a way that relying solely on the logic of higher supply equals lower prices and higher demand equals higher prices may not be adequate (valid) in today's environment. Alternatively, it is suggested that pricing decisions should be based on as much relevant information as possible if managers want to achieve optimal room rate, which will offer optimal revenue while maintaining high customer satisfaction. El-Nemr et al. (2017) also argue that although consumer behaviour has been neglected, it is an important factor that should be incorporated in the pricing strategies since hotel guests have increased access to information. Noteworthy mentioning is that different hotel and room attributes or characteristics don't have equal influence on the final room rate (Thrane, 2006). Hence, hotels need to be able to evaluate the value assigned by guests for each attribute and emphasize the attributes which affect the price in a positive manner while removing or reducing the non-value adding attributes.

Aside from the aforementioned, customer's perception regarding the value for money received is another factor which may affect the room rate in the hospitality industry (Santos \& Flores, 2017). Stated differently, the room price can be seen as a combination of different features which create certain value and affect the customer's willingness to pay the defined price (Zhang et al., 2011).

Although there are tens or even hundreds of factors which may potentially affect the price charged by hotels, every factor doesn't have equal weight in the pricing decision. Moreover, while there are some universal factors which are applicable to a large number of hotels, there 
are also factors which are characteristics for the specific city, region or country (Du Plessis \& Saayman, 2011). Hence, instead of full replication of pricing strategy from other hotels, each hotel needs to define a pricing strategy which is customized to the specific hotel characteristics, circumstances and surrounding.

\subsection{Overview of pricing strategies in the hospitality industry}

At a very basic level, the price can be perceived as the process of assigning a monetary value to a specific product or service. However, the role of the price may also be considered from the marketing side or from the customer's point of view. Accordingly, the price may be used as a marketing tool to attract customers as long as they accept to pay the specific price, while from the customer's point of view the price shows the level of quality they could expect when they purchase a product (Kim et al., 2004).

The decision on the most appropriate pricing strategy depends on a number of factors surrounding the specific hotel as well as the hotel industry. At a fundamental level, companies may choose to use static or dynamic pricing approaches to define the adequate selling price. The static approach is based around the notion that the price doesn't experience any drastic changes throughout the specified period or throughout the year. Thus, hotels using some of the static pricing strategies will retain the same room rate irrespective of the room occupancy rate, demand and supply or changes in the environment. On the other hand, dynamic pricing strategies are strategies where hotels will adjust their room rates in accordance with the changes in a variety of factors (Beck et al., 2018). For example, changes in the supply and demand levels will increase or decrease the room rates. When applying dynamic pricing, hotels are able to easily adapt to changes in the market and enjoy an adequate level of occupancy rate even in periods of low demand.

The importance of setting an optimal price stimulated the development of various pricing methods which differ in terms of the factors which are included in the pricing decision and the price calculation process. Cost-plus pricing may be one of the simplest pricing methods for hotel industry due to the way in which room rates are determined. Namely, the price is formed with the associated direct and/or indirect costs and the addition of a prespecified markup. Under the cost-plus method, managers can decide to use some of the basic strategies to derive the respective room rate. Accordingly, the available strategies may include full cost-plus pricing and direct cost-plus pricing. The full cost-plus pricing considers all costs plus a percentage markup that represents the profit. On the other hand, direct cost-plus strategy relies primarily on the direct cost associated with the service offered and the plus markup is composed of indirect expenses and the planned net profit.

Although the cost-plus pricing method may have its advantages, some argue that this method may be obsolete in an industry which is characterized by a higher level of competition. Accordingly, hotels may resort towards competitive pricing approaches if they operate in an environment with increased competition (Kim et al., 2004). The competition-based approach is a rather simple method to define hotel prices as it is based on the prices charged by competitors. Hotels will determine their prices in accordance with the prices charged by other hotels (Sammut-Bonnici \& Channon, 2014). Nevertheless, this type of pricing strategy may lead toward overpricing or underpricing of rooms and eliminate the possibility for setting an optimal room price.

Market based pricing approach is also a move away from the cost-based pricing, where higher weight is given to the supply and demand for the specific services in the market. Accordingly, the economic logic is followed when setting the prices, which means that prices 
will rise when the demand exceeds the supply while there will be a price decrease when the supply exceeds the demand.

Value-based pricing strategy is also used by hotels in their efforts to define an adequate room rate. This approach is centered on the value perceived by the customers, which make this value the starting point when defining room prices (Beck et al., 2018). Hotels may be able to charge higher prices by offering additional attributes or perks for basic packages which will differentiate them from the competition and give the impression of providing higher value.

Pricing method used in the hotel industry is also the hedonic pricing model which is centered on the idea that the room price is calculated by summing unobserved or implicate prices related to a set of room attributes (Castro \& Ferreira, 2018). In other words, this model is based on the assumption that although each of the individual attributes and characteristics cannot be sold separately, their values can be added to form a room price. Hotels then have the opportunity to define their room rate based on the existence or lack of the attributes which may influence the overall hotel quality and the desire of guests to choose the specific hotel.

Hotels have the option to apply advanced methods such as forecasting models to forecast the hotel room rates (Zheng et al., 2020). Moreover, the room rate may be forecasted on a daily basis by predicting the potential demand and the inclusion of other crucial factors.

Aside from the above stated pricing strategy, there are also other pricing strategies which may be utilized by decision makers to define adequate room rates. Discount pricing represents an approach which may be applied by hotels where seasonality has a major impact on their room occupancy rate. Accordingly, this approach considers the option for hotels to charge lower prices (at a discount) during low seasons in an attempt to maintain a certain level of occupancy and generate additional revenue through other services. Some hotels may also apply the strategy to define prices based on the length of stay by imposing a minimum number of days that should be reserved. This strategy may be suitable during the periods of high demand or in locations where demand exceeds the supply. Hotels may also define different packages for specific types or groups of customers if they follow the price per segment approach. For instance, they could offer a newlyweds rate, happy couple rates and so on. Furthermore, some hotels, especially the ones that are part of a well-established hotel chain, may follow a so-called positional pricing strategy. In this approach, the brand and reputation strength will have a major influence on the prices (Brzaković et al., 2019) and highly reputable hotels may even charge a premium due to their brand even when they offer the same attributes as their competitors.

It is obvious that there is an overwhelming number of pricing strategies suggested by the literature as well as strategies used by hotels. The common aspects of these strategies are that the factors affecting the pricing decisions are modified or broadened to account for the appearance of new factors coming from a variety of developments and increased access to information.

\section{Materials and methods}

Hotels set their room rates using different pricing strategies which incorporate the influence of a variety of factors as well as the value added by different attributes. Consequently, the aim of this research is to examine the size of the existing discrepancy among hotels operating in the same city and belong to the same category in terms of the number of stars as stated by Booking.com. 
Temelkov, Z. - Overview of price discrepancies among hotels positioned in the same category -

Hotel and Tourism Management, 2020, Vol. 8, No. 2: 11-23.

The data used for the analysis is manually gathered from the online booking platform Booking.com. The lowest and the highest prices demanded by hotels for a one-night stay for two people during a prespecified date were collected for each city individually for each star category separately. A total of 34 capital cities in Europe were included in the analysis, while the categories where only two hotels were available for the selected date were excluded from the analysis.

For the purpose of the analysis, primarily the monetary difference in euro was calculated between the highest and the lowest price. Afterwards, the percentage difference is estimated where the lowest value is set as the base value and the starting point that customers will receive the basic services when paying the lowest price in the category. By doing so, there is an opportunity to see the value that is added on top of the basic price when customers want to enjoy a higher level of amenities along with the value coming from different factors.

The research is faced with couple of limitations when it comes to the data used in the analysis. First, the hotels included in the analysis are hotels which had available room for the selected date, which means that all hotels operating in the specific city were not included in the analysis. Second, while some hotels may conduct their business activities during specific seasons, the effects coming from seasonality were not included in the analysis. Lastly, this research doesn't consider the factors which cause the potential price discrepancy as suggested by the literature.

\section{Results and discussion}

The results obtained through the analysis of data gathered from Booking.com are observed for each category of hotels separately. Structuring the analysis in this manner enables easier observance of the potential results and reaching the relevant findings. The findings provide a practical overview of the influence of relevant factors on the final room price, as suggested by the literature. Starting with hotels belonging in the highest star category, the results for each category are presented in the following tables.

Table 1: Price discrepancies among five stars hotels in selected cities

\begin{tabular}{|l|l|c|c|c|c|c|}
\hline Country & City & Stars & $\begin{array}{c}\text { Lowest } \\
\text { price per } \\
\text { night } €\end{array}$ & $\begin{array}{c}\text { Highest } \\
\text { price per } \\
\text { nigh } €\end{array}$ & $\begin{array}{c}\text { Difference } \\
€\end{array}$ & $\begin{array}{c}\text { Difference } \\
\%\end{array}$ \\
\hline UK & London & 5 & 98 & 2,873 & 2,775 & $2,832 \%$ \\
\hline Czech & Prague & 5 & 42 & 899 & 857 & $2,040 \%$ \\
\hline Greece & Athens & 5 & 96 & 886 & 790 & $823 \%$ \\
\hline Netherlands & Amsterdam & 5 & 129 & 900 & 771 & $598 \%$ \\
\hline Italy & Rome & 5 & 133 & 913 & 780 & $586 \%$ \\
\hline Spain & Madrid & 5 & 50 & 340 & 290 & $580 \%$ \\
\hline Austria & Vienna & 5 & 109 & 676 & 567 & $520 \%$ \\
\hline Latvia & Riga & 5 & 60 & 350 & 290 & $483 \%$ \\
\hline Hungary & Budapest & 5 & 95 & 525 & 430 & $453 \%$ \\
\hline Portugal & Lisbon & 5 & 117 & 590 & 473 & $404 \%$ \\
\hline Denmark & Copenhagen & 5 & 177 & 792 & 615 & $347 \%$ \\
\hline Sweden & Stockholm & 5 & 123 & 480 & 357 & $290 \%$ \\
\hline Poland & Warsaw & 5 & 60 & 224 & 164 & $273 \%$ \\
\hline
\end{tabular}


Temelkov, Z. - Overview of price discrepancies among hotels positioned in the same category Hotel and Tourism Management, 2020, Vol. 8, No. 2: 11-23.

\begin{tabular}{|l|l|c|c|c|c|c|}
\hline Belgium & Brussels & 5 & 94 & 279 & 185 & $197 \%$ \\
\hline Lithuania & Vilnius & 5 & 107 & 300 & 193 & $180 \%$ \\
\hline Germany & Berlin & 5 & 109 & 297 & 188 & $172 \%$ \\
\hline Serbia & Belgrade & 5 & 90 & 239 & 149 & $166 \%$ \\
\hline Norway & Oslo & 5 & 149 & 374 & 225 & $151 \%$ \\
\hline Moldova & Chișinău & 5 & 63 & 144 & 81 & $129 \%$ \\
\hline Finland & Helsinki & 5 & 112 & 256 & 144 & $129 \%$ \\
\hline Ireland & Dublin & 5 & 179 & 332 & 153 & $85 \%$ \\
\hline Bulgaria & Sofia & 5 & 63 & 115 & 52 & $83 \%$ \\
\hline Belarus & Minsk & 5 & 91 & 157 & 66 & $73 \%$ \\
\hline Romania & Bucharest & 5 & 74 & 127 & 53 & $72 \%$ \\
\hline Estonia & Tallin & 5 & 117 & 197 & 80 & $68 \%$ \\
\hline Croatia & Zagreb & 5 & 94 & 148 & 54 & $57 \%$ \\
\hline Ukraine & Kyiv & 5 & 94 & 126 & 32 & $34 \%$ \\
\hline Andora & Andorra la Vella & 5 & 95 & 122 & 27 & $28 \%$ \\
\hline Slovakia & Bratislava & 5 & 124 & 144 & 20 & $16 \%$ \\
\hline
\end{tabular}

Source: Author's research

The findings for five stars category indicate that there may be a price difference of more than $2,000 \%$ between the lowest and the highest price charged by hotels in London and Prague. At the same time, the third highest discrepancy of more than $800 \%$ is identified between hotels in Athens. Such a substantial price discrepancy implies that guests will experience a sizable difference in room attributes and service quality in the aforementioned cities. On the other hand, the lowest difference in price and consequently, the difference in value received is detected in Bratislava with a price difference of only $16 \%$.

Table 2: Price discrepancies among four stars hotels in selected cities

\begin{tabular}{|l|l|c|c|c|c|c|}
\hline Country & City & Stars & $\begin{array}{c}\text { Lowest } \\
\text { price per } \\
\text { night } €\end{array}$ & $\begin{array}{c}\text { Highest } \\
\text { price per } \\
\text { nigh } €\end{array}$ & $\begin{array}{c}\text { Difference } \\
€\end{array}$ & $\begin{array}{c}\text { Difference } \\
\%\end{array}$ \\
\hline Italy & Rome & 4 & 39 & 375 & 336 & $862 \%$ \\
\hline Czech & Prague & 4 & 34 & 300 & 266 & $782 \%$ \\
\hline Slovenia & Ljubljana & 4 & 62 & 500 & 438 & $706 \%$ \\
\hline Poland & Warsaw & 4 & 35 & 269 & 234 & $669 \%$ \\
\hline Spain & Madrid & 4 & 59 & 384 & 325 & $551 \%$ \\
\hline Greece & Athens & 4 & 44 & 279 & 235 & $534 \%$ \\
\hline UK & London & 4 & 50 & 299 & 249 & $498 \%$ \\
\hline Croatia & Zagreb & 4 & 45 & 260 & 215 & $478 \%$ \\
\hline Germany & Berlin & 4 & 58 & 296 & 238 & $410 \%$ \\
\hline Ukraine & Kyiv & 4 & 31 & 158 & 127 & $410 \%$ \\
\hline Netherlands & Amsterdam & 4 & 65 & 320 & 255 & $392 \%$ \\
\hline Denmark & Copenhagen & 4 & 107 & 524 & 417 & $390 \%$ \\
\hline
\end{tabular}


Temelkov, Z. - Overview of price discrepancies among hotels positioned in the same category -

Hotel and Tourism Management, 2020, Vol. 8, No. 2: 11-23.

\begin{tabular}{|c|c|c|c|c|c|c|}
\hline Austria & Vienna & 4 & 54 & 240 & 186 & $344 \%$ \\
\hline Portugal & Lisbon & 4 & 55 & 230 & 175 & $318 \%$ \\
\hline Serbia & Belgrade & 4 & 33 & 137 & 104 & $315 \%$ \\
\hline Hungary & Budapest & 4 & 44 & 175 & 131 & $298 \%$ \\
\hline Bulgaria & Sofia & 4 & 42 & 155 & 113 & $269 \%$ \\
\hline Lithuania & Vilnius & 4 & 38 & 139 & 101 & $266 \%$ \\
\hline Romania & Bucharest & 4 & 32 & 109 & 77 & $241 \%$ \\
\hline Norway & Oslo & 4 & 74 & 238 & 164 & $222 \%$ \\
\hline Slovakia & Bratislava & 4 & 48 & 154 & 106 & $221 \%$ \\
\hline Ireland & Dublin & 4 & 71 & 225 & 154 & $217 \%$ \\
\hline Latvia & Riga & 4 & 37 & 117 & 80 & $216 \%$ \\
\hline Sweden & Stockholm & 4 & 69 & 209 & 140 & $203 \%$ \\
\hline Estonia & Tallin & 4 & 49 & 145 & 96 & $196 \%$ \\
\hline Moldova & Chișinău & 4 & 41 & 120 & 79 & $193 \%$ \\
\hline Belgium & Brussels & 4 & 59 & 152 & 93 & $158 \%$ \\
\hline Andora & Andorra la Vella & 4 & 45 & 95 & 50 & $111 \%$ \\
\hline Finland & Helsinki & 4 & 87 & 178 & 91 & $105 \%$ \\
\hline Liechtenstein & Vaduz & 4 & 151 & 307 & 156 & $103 \%$ \\
\hline Switzerland & Bern & 4 & 122 & 196 & 74 & $61 \%$ \\
\hline Malta & Valletta & 4 & 126 & 162 & 36 & $29 \%$ \\
\hline Belarus & Minsk & 4 & 67 & 83 & 16 & $24 \%$ \\
\hline
\end{tabular}

Source: Author's research

The finding for the category of four stars hotels signals that there is a much lower price discrepancy among hotels in this category compared to the discrepancy in the previous category. Accordingly, the highest price difference is evident in Rome with 862\%, Prague with $782 \%$ and Ljubljana with $706 \%$. Nevertheless, the lowest percentage difference of $24 \%$ appears among hotels in Minsk.

Table 3: Price discrepancies among three stars hotels in selected cities

\begin{tabular}{|l|l|c|c|c|c|c|}
\hline Country & City & Stars & $\begin{array}{c}\text { Lowest } \\
\text { price per } \\
\text { night } €\end{array}$ & $\begin{array}{c}\text { Highest } \\
\text { price per } \\
\text { nigh } €\end{array}$ & $\begin{array}{c}\text { Difference } \\
€\end{array}$ & $\begin{array}{c}\text { Difference } \\
\%\end{array}$ \\
\hline Italy & Rome & 3 & 31 & 957 & 926 & $2,987 \%$ \\
\hline Sweden & Stockholm & 3 & 44 & 970 & 926 & $2,105 \%$ \\
\hline Hungary & Budapest & 3 & 23 & 456 & 433 & $1,883 \%$ \\
\hline UK & London & 3 & 33 & 507 & 474 & $1,436 \%$ \\
\hline Greece & Athens & 3 & 30 & 300 & 270 & $900 \%$ \\
\hline Czech & Prague & 3 & 24 & 150 & 126 & $525 \%$ \\
\hline Ukraine & Kyiv & 3 & 15 & 89 & 74 & $493 \%$ \\
\hline Ireland & Dublin & 3 & 62 & 340 & 278 & $448 \%$ \\
\hline
\end{tabular}


Temelkov, Z. - Overview of price discrepancies among hotels positioned in the same category Hotel and Tourism Management, 2020, Vol. 8, No. 2: 11-23.

\begin{tabular}{|l|l|c|c|c|c|c|}
\hline Austria & Vienna & 3 & 34 & 173 & 139 & $409 \%$ \\
\hline Germany & Berlin & 3 & 42 & 209 & 167 & $398 \%$ \\
\hline Netherlands & Amsterdam & 3 & 45 & 219 & 174 & $387 \%$ \\
\hline Bulgaria & Sofia & 3 & 15 & 69 & 54 & $360 \%$ \\
\hline Romania & Bucharest & 3 & 25 & 109 & 84 & $336 \%$ \\
\hline Portugal & Lisbon & 3 & 42 & 176 & 134 & $319 \%$ \\
\hline Latvia & Riga & 3 & 20 & 77 & 57 & $285 \%$ \\
\hline Spain & Madrid & 3 & 36 & 132 & 96 & $267 \%$ \\
\hline Slovenia & Ljubljana & 3 & 40 & 143 & 103 & $258 \%$ \\
\hline Poland & Warsaw & 3 & 24 & 83 & 59 & $246 \%$ \\
\hline Slovakia & Bratislava & 3 & 28 & 89 & 61 & $218 \%$ \\
\hline Andora & Andorra la Vella & 3 & 35 & 110 & 75 & $214 \%$ \\
\hline Estonia & Tallin & 3 & 38 & 117 & 79 & $208 \%$ \\
\hline Serbia & Belgrade & 3 & 28 & 80 & 52 & $186 \%$ \\
\hline Belarus & Minsk & 3 & 26 & 71 & 45 & $173 \%$ \\
\hline Belgium & Brussels & 3 & 48 & 129 & 81 & $169 \%$ \\
\hline Lithuania & Vilnius & 3 & 35 & 85 & 50 & $143 \%$ \\
\hline Croatia & Zagreb & 3 & 45 & 98 & 53 & $118 \%$ \\
\hline Norway & Oslo & 3 & 65 & 129 & 64 & $98 \%$ \\
\hline Denmark & Copenhagen & 3 & 80 & 154 & 74 & $93 \%$ \\
\hline Switzerland & Bern & 3 & 112 & 214 & 102 & $91 \%$ \\
\hline Cyprus & Nicosia & 3 & 60 & 109 & 49 & $82 \%$ \\
\hline Moldova & Chișinău & 3 & 23 & 36 & 13 & $57 \%$ \\
\hline Finland & Helsinki & 3 & 84 & 103 & 19 & $23 \%$ \\
\hline SourCe: Author & sresearch & & & & & \\
\hline
\end{tabular}

Source: Author's research

The results regarding the difference between the three stars hotels are quite interesting as the three highest price discrepancies in this category are also higher than the discrepancies found in the hotels with five stars and four stars. Accordingly, the highest price difference is found between hotels in Rome, Stockholm and Budapest with a difference of 2,987\%, 2,105\% and $1,883 \%$ respectively.

While three stars category has the highest identified discrepancy across hotels from all categories, the lowest price difference in this category is identified among hotels in Helsinki with a difference of $23 \%$ which is similar to the smallest discrepancies in five and four stars categories. 
Temelkov, Z. - Overview of price discrepancies among hotels positioned in the same category-

Hotel and Tourism Management, 2020, Vol. 8, No. 2: 11-23.

Table 4: Price discrepancies among two stars hotels in selected cities

\begin{tabular}{|c|c|c|c|c|c|c|}
\hline Country & City & Stars & $\begin{array}{c}\text { Lowest } \\
\text { price per } \\
\text { night } €\end{array}$ & $\begin{array}{c}\text { Highest } \\
\text { price per } \\
\text { nigh } €\end{array}$ & $\begin{array}{c}\text { Difference } \\
€ \\
\end{array}$ & $\begin{array}{c}\text { Difference } \\
\% \\
\end{array}$ \\
\hline UK & London & 2 & 34 & 421 & 387 & $1,138 \%$ \\
\hline Italy & Rome & 2 & 18 & 144 & 126 & $700 \%$ \\
\hline Germany & Berlin & 2 & 23 & 110 & 87 & $378 \%$ \\
\hline Belarus & Minsk & 2 & 15 & 56 & 41 & $273 \%$ \\
\hline Greece & Athens & 2 & 30 & 110 & 80 & $267 \%$ \\
\hline Bulgaria & Sofia & 2 & 16 & 51 & 35 & $219 \%$ \\
\hline Sweden & Stockholm & 2 & 48 & 149 & 101 & $210 \%$ \\
\hline Netherlands & Amsterdam & 2 & 53 & 159 & 106 & $200 \%$ \\
\hline Denmark & Copenhagen & 2 & 54 & 140 & 86 & $159 \%$ \\
\hline Spain & Madrid & 2 & 50 & 129 & 79 & $158 \%$ \\
\hline Finland & Helsinki & 2 & 40 & 103 & 63 & $158 \%$ \\
\hline Belgium & Brussels & 2 & 46 & 115 & 69 & $150 \%$ \\
\hline Portugal & Lisbon & 2 & 34 & 80 & 46 & $135 \%$ \\
\hline Poland & Warsaw & 2 & 31 & 71 & 40 & $129 \%$ \\
\hline Moldova & Chișinău & 2 & 21 & 41 & 20 & $95 \%$ \\
\hline Cyprus & Nicosia & 2 & 55 & 106 & 51 & $93 \%$ \\
\hline Romania & Bucharest & 2 & 23 & 43 & 20 & $87 \%$ \\
\hline Ireland & Dublin & 2 & 73 & 129 & 56 & $77 \%$ \\
\hline Ukraine & Kyiv & 2 & 21 & 37 & 16 & $76 \%$ \\
\hline Czech & Prague & 2 & 27 & 47 & 20 & $74 \%$ \\
\hline Austria & Vienna & 2 & 50 & 85 & 35 & $70 \%$ \\
\hline Croatia & Zagreb & 2 & 38 & 58 & 20 & $53 \%$ \\
\hline Estonia & Tallin & 2 & 33 & 50 & 17 & $52 \%$ \\
\hline Malta & Valletta & 2 & 60 & 90 & 30 & $50 \%$ \\
\hline Andora & Andorra la Vella & 2 & 30 & 43 & 13 & $43 \%$ \\
\hline Slovakia & Bratislava & 2 & 40 & 56 & 16 & $40 \%$ \\
\hline Switzerland & Bern & 2 & 109 & 139 & 30 & $28 \%$ \\
\hline Latvia & Riga & 2 & 35 & 41 & 6 & $17 \%$ \\
\hline
\end{tabular}

Source: Author's research

Hotels in London, Rome and Berlin have the highest price discrepancies among two stars hotels with their respective differences in the price of $1,138 \%, 700 \%$ and $378 \%$. Alternatively, the smallest price discrepancy exists between hotels conducting their activities in Riga with a difference of $17 \%$. 
Table 5: Cities with highest differences in hotel room rates

\begin{tabular}{|c|c|c|c|c|c|c|c|c|}
\hline \multirow{2}{*}{$\begin{array}{c}\text { Cities with } \\
\text { highest } \\
\text { price }\end{array}$} & \multicolumn{2}{|c|}{ Five stars } & \multicolumn{2}{c|}{ Four stars } & \multicolumn{2}{c|}{ Three stars } & \multicolumn{2}{c|}{ Two stars } \\
\cline { 2 - 9 } differences & London & $2,832 \%$ & Rome & $862 \%$ & Rome & $2,987 \%$ & London & $1,138 \%$ \\
\cline { 2 - 9 } & Prague & $2,040 \%$ & Prague & $782 \%$ & Stockholm & $2,105 \%$ & Rome & $700 \%$ \\
\cline { 2 - 9 } & Athens & $823 \%$ & Ljubljana & $706 \%$ & Budapest & $1,883 \%$ & Berlin & $378 \%$ \\
\hline
\end{tabular}

Source: Author's research

The results also show that hotels operating in London and Rome have the highest price discrepancies in two categories. In other words, hotels in London hold the position for highest price difference among five stars and two stars hotels while guests of four stars and three stars hotels will experience the highest difference in room rates in Rome. Also, Rome is found once more in the top three positions among hotels with the highest price difference. It can be noted that all cities found among the top three positions in respect to the price discrepancy are also well-known and highly desirable tourist destinations in Europe.

It can be said that although hotels may belong to the same category, guests may enjoy large variations in the quality and the amenities of the hotels and the rooms. Accordingly, the same star category is not a guarantee for the same level of services and room quality and based on the room rates guests may choose the level of comfort they want to enjoy.

\section{Conclusion}

Price is a crucial factor when it comes to the process of attracting customers and maintaining a base of loyal guests. Hence, hotels pay special attention to define a price, which will fully reflect the level of quality of their rooms and provide value for money demanded by guests. Hotels define room prices through the application of a pricing method which is most appropriate based on the hotel characteristics and its surroundings. The process of calculating the optimal room prices means that hotels need to include a variety of factors which affect the final price. Therefore, there are certain price differences even among hotels that belong to the same category.

The findings of this research are in line with the literature which stipulates that hotels in the same category may set different room rates based on the weight of relevant factors and whether the hotels employ a hedonic, dynamic or some of the other pricing strategies (Sanchez-Pérez et al., 2019; Soler \& Gémar, 2016; Yalcin \& Mert, 2018). Accordingly, a substantial difference of more than two thousand per cents in prices has been identified between hotels with the same number of stars. This implies that customers can expect a consistency only at the basic level of services whereas the quality of additional services, as well as the overall value, will largely depend on the price they are willing to pay.

Analysis performed in this research has identified the price discrepancies among hotels only at certain fundamental level. Nevertheless, the analysis and findings set the ground for future research which should be aimed at better understanding of the reasons and factors that lead toward sizable discrepancies among hotels in the same categories. Future analysis may be conducted with the aim of identifying factors which are common to a large number of hotels and factors relevant to specific hotels and cities.

The analysis may also be performed to see whether the price differences for hotels in the same star category are justified based on the value and quality of additional services offered by hotels with higher prices. Also, examining the effect coming from the brand and hotel reputation on hotel room rates may be of special interest. This is in a sense to see whether 
well-known hotels or hotel chains are able to charge a premium above the price of their competitors for the same level of services.

Examining the effect coming from the level of economic development and living standards on hotel price may also be of interest for future analysis. Namely, the research may show whether hotels operating in economies with lower economic development or lower living standards will lead to lower prices even when the quality of services is the same as in hotels in developed countries.

\section{References}

1. Abrate, G., \& Viglia, G. (2016). Strategic and tactical price decisions in hotel revenue management. Tourism Management, 55, 123-132. https://doi.org/10.1016/j.tourman.2016.02.006

2. Beck, J. A., Kim, M., \& Schmidgall, R. S. (2018). The pricing for same-day arrival guests in the hotel industry. International Journal of Business and Applied Social Science, 4(1), 1-18.

3. Brzaković, A., Brzaković, T., \& Brzaković, P. (2019). Izgradnja tržišne vrednosti brenda [Creating brand market value]. Anali Ekonomskog fakulteta u Subotici, 55(42), 17-33. https://doi.org/10.5937/AnEkSub1942017B

4. Castro., C., \& Ferreira, A., F. (2018). Online hotel ratings and its influence on hotel room rates: The case of Lisbon, Portugal. Tourism \& Management Studies, 14(11), 6372. https://doi.org/10.18089/tms.2018.14SI107

5. Du Plessis, E., \& Saayman, M. (2011). Factors influencing pricing in the accommodation sector in South Africa. The Southern African Journal of Entrepreneurship and Small Business Management, 4(1), 24-47. https://doi.org/10.4102/sajesbm.v4i1.22

6. El-Nemr, N., Canel-Depitre, B., \& Taghipour, A. (2017). Determinants of hotel room rates. Marketing Trends Congress. Luxury Industries Conference London, London, United Kingdom.

7. Ilić, I., \& Nikolić, A. (2018). Implications of modern technology development for the tourism sector of the Republic of Serbia. Ekonomika, 64(1), 37-52. https://doi.org/10.5937/ekonomika1801037I

8. Jovanović, S. (2019). Green hotels as a new trend in the function of sustainable development and competitiveness improvement. Economics of Sustainable Development, 3(1), 1-7. https://doi.org/10.5937/ESD1901001J

9. Kim, W. G., Han, J., \& Hyun, K. (2004). Multi-stage synthetic hotel pricing. Journal of Hospitality \& Tourism Research, 28(2), 166-185. https://doi.org/10.1177/1096348004264082

10. Sammut-Bonnici, T., \& Channon, D. F. (2014). Pricing strategy. Wiley Encyclopedia of Management, John Wiley \& https://doi.org/10.1002/9781118785317.weom120162

11. Santos, M., \& Flores, L. C. S. (2017). Price formation of tourist hotels of the City of São Luís/Maranhão. Brazilian Journal of Tourism Research, 11(1), 133-153. http://dx.doi.org/10.7784/rbtur.v11i1.1169

12. Sánchez-Pérez, M., Dolores Illescas-Manzano, M., \& Martínez-Puertas, S. (2019). Modeling hotel room pricing: A multi-country analysis. International Journal of Hospitality Management, 79, 89-99. https://doi.org/10.1016/j.ijhm.2018.12.014

13. Soler, I. P., \& Gémar, G. (2016). The impact of family business strategies on hotel room prices. European Journal of Family Business, 6(1), 54-61. https://doi.org/10.1016/j.ejfb.2016.06.003 
14. Thrane, C. (2006). Examining the determinants of room rates for hotels in capital cities: The Oslo experience. Journal of Revenue \& Pricing Management, 5(4), 315-323. https://doi.org/10.1057/palgrave.rpm.5160055

15. Yalcin, F., \& Mert, M. (2018). Determination of hedonic hotel room prices with spatial effect in Antalya. Economía, Sociedad y Territorio, 18(58), 697-734. http://dx.doi.org/10.22136/est20181228

16. Zhang, Z., Ye, Q., \& Law, R. (2011). Determinants of hotel room price: An exploration of travelers' hierarchy of accommodation needs. International Journal of Contemporary Hospitality Management, 23(7), 972-981. https://doi.org/10.1108/09596111111167551

17. Zheng, T., Liu, S., Chen, Z., Qiao, Y., \& Law, R. (2020). Forecasting daily room rates on the basis of an LSTM model in difficult times of Hong Kong: Evidence from online distribution channels in the hotel industry. Sustainability, 12(18), 7334. https://doi.org/10.3390/su12187334 